\title{
Analysis of the potentially life threatening conditions of women in intensive care units
}

\author{
Análise das condições potencialmente ameaçadoras de vida de mulheres em unidade de \\ terapia intensiva
}

Alana Santos Monte ${ }^{1}$, Liana Mara Rocha Teles ${ }^{1}$, Camila Chaves da Costa ${ }^{1}$, Linicarla Fabíole de Souza Gomes ${ }^{2}$, Ana Kelve de Castro Damasceno ${ }^{1}$

Objective: to describe the main potentially life threatening conditions of women hospitalized in a maternal intensive care unit and their association with sociodemographic and obstetric variables. Methods: a crosssectional epidemiological study was carried out with 560 women admitted to an Intensive Care Unit. Results: the most prevalent conditions were: use of blood products and severe preeclampsia/eclampsia. There was a statistical association between women from the metropolitan region, in the age group of 20 to 34 years and who had previously given birth. Mothers who had a potentially life threatening condition presented a higher chance of having a child with Apgar $<7$ in the fifth minute and weigh of less than 1,500g. Conclusion: the use of blood products prevailed, followed by severe preeclampsia and eclampsia. A strong relation was identified between the origin, parity and potentially life threatening conditions, as well as between these and negative perinatal outcomes.

Descriptors: Morbidity; Maternal Health; Nursing.

Objetivo: descrever as principais condições potencialmente ameaçadoras de vida de mulheres internadas em uma unidade de terapia intensiva materna e a associação destas com as variáveis sociodemográficas e obstétricas. Métodos: estudo epidemiológico analítico transversal, realizado com 560 mulheres internadas em uma Unidade de Terapia Intensiva. Resultados: as condições mais prevalentes foram: utilização de hemoderivados e pré-eclampsia grave/eclampsia. Houve associação estatística entre mulheres procedentes da região metropolitana, na faixa etária de 20 a 34 anos e que tiveram um parto anterior. A mãe que teve alguma condição potencialmente ameaçadora de vida apresentou maior chance de ter filho com Apgar $<7$ no quinto minuto e com peso menor que 1.500g. Conclusão: prevaleceram a utilização de hemoderivados, seguida da pré-eclampsia grave e da eclampsia. Identificou-se forte relação entre a procedência, paridade e as condições potencialmente ameaçadoras de vida, bem como associação entre estas e os desfechos perinatais negativos.

Descritores: Morbidade; Saúde Materna; Enfermagem.

\footnotetext{
${ }^{1}$ Universidade Federal do Ceará. Fortaleza, CE, Brazil.

${ }^{2}$ Faculdade Metropolitana da Grande Fortaleza. Fortaleza, CE, Brazil. 


\section{Introduction}

Maternal death is defined as the death of a woman during gestation or within a period of 42 days after the termination of this state, regardless of its duration or location, for any cause related or aggravated by the pregnancy of procedures related to it, excluding here the accidental or incidental causes ${ }^{(1)}$.

In Brazil, maternal death is still a public health problem and, according to data from the Ministry of Health, the last available data indicate a Mortality Ratio of 69 deaths per 100,000 live births in 2013, being considered a high index. The North and Northeast regions have the worst indicators. In Ceará, the average Maternal Mortality Ratio was 75.6 maternal deaths per 100,000 live births, $85.5 \%$ of which were due to direct or indirect obstetric causes, while the South and Southeast regions have the lowest Maternal Mortality Ratio $^{(2-3)}$.

Research has shown that maternal mortality represents only the tip of an iceberg, in which several women survive complications during pregnancy, childbirth and puerperium, and may have different degrees of sequelae ${ }^{(4)}$.

In view of this, a new condition - severe maternal morbidity or maternal near miss - has been studied for more than two decades. The definition of maternal near miss refers to a woman who was close to dying and survived a complication during gestation, delivery or up to 42 days after termination of pregnancy ${ }^{(5)}$.

This standardization made it possible to classify the maternal population in an evolutionary line of gravity in eight potentially life threatening conditions, with five complications: severe post-partum hemorrhage, severe preeclampsia, eclampsia, sepsis/severe systemic infection, and uterine rupture; and three critical interventions: blood transfusions, interventional radiology, and laparotomy (including hysterectomy and other emergency surgeries in the abdominal cavity, but excluding cesarean section) ${ }^{(6)}$.

Besides increasing maternal morbidity, Near miss is also know to possibly contribute to the increase of perinatal morbidity and mortality and risk of live births with Threatening Life Conditions at birth ${ }^{(7)}$. These conditions are: 5-minute Apgar score less than 7 or birth weight less than 1,500 g or Gestational Age at the time of birth less than 30 weeks ${ }^{(8)}$.

In this context, the following question applies: What are the potentially life threatening conditions present in these women hospitalized in intensive care units? And what are the relationships between them and maternal and fetal variables?

The study is justified by the importance of research making an in-depth analysis of maternal and neonatal morbidity and mortality. In addition, it is of paramount importance that practitioners be able to identify the major causes of death that, most of the times, can be avoided.

Thus, the objective of this work is to describe the main potentially life threatening conditions of women hospitalized in maternal intensive care units and their associations with sociodemographic and obstetric variables.

\section{Methods}

Analytical, cross-sectional epidemiological study. Data collection took place from July to December 2015 at the Assis Chateaubriand Maternity School, which is a reference maternity hospital in the State of Ceará, Brazil, linked to the Unified Health System.

The study population consisted of all 882 records of women who were admitted to the intensive care unit during the period from 2010 to 2014, and the respective records of newborns of these women; data was obtained through the records of hospitalizations in the sector. Exclusion criteria used to select the records were: puerperal women who had given birth for more than 42 days; charts with incomplete data (without obstetric hospitalization data) or missing; and cases of gynecological complications. Thus, 322 medical records were excluded, leaving a sample of 560. All medical records of newborns born in the 
institution that were attached to the mother's records were selected, totaling 380 .

The instrument for data collection was adapted ${ }^{(9)}$ from the individual form published by the World Health Organization for implementation of Near Miss maternal research within health services. The instrument covers sociodemographic data such as age, marital status, origin, schooling, color, occupation. Obstetric data such as history, with previous gestational history related to the number of pregnancies (cesarean and vaginal delivery), number of abortions, number of live births, number of fetal deaths and History of Current Gestation with the number of prenatal consultations, diagnosis at admission, number of days of hospitalization, length of hospitalization in the Intensive Care Unit, delivery route, gestational age at delivery and maternal habits. The variables of life threatening conditions including severe postpartum haemorrhage, severe preeclampsia, eclampsia, sepsis or severe systemic infection, uterine rupture, use of blood products (including any blood transfusion), interventional radiology (uterine artery embolization) and laparotomy. Finally, the variables related to the infant including gestational age at the time of delivery birth weight; Apgar score at the fifth minute and neonatal outcome.

Data were compiled and analyzed in the statistical program Statistical Package for the Social Sciences version 20.0. The exploratory analysis consisted of descriptive statistical tests, absolute and relative frequencies, averages, medians and standard deviations, presented in tables and graphs, and discussed according to pertinent literature. To evaluate the association between variables, the Chi-square test and the gross Odds Ratio (OR) were used, and to check the intensity of this associations, gross prevalence ratios were adjusted. In the multivariate analysis, logistic regression and Adjusted Odds Ratio were used.

The study complied with the formal requirements contained in the national and international regulatory standards for research involving human beings.

\section{Results}

From 560 analyzed records, 119 (21.2\%) did not meet the criteria of potentially life threatening conditions or maternal Near miss; 441 (78.8\%) women had at least one complication that placed them as women with potentially life threatening conditions; of these, 215 were included in the criterion of maternal Near miss and 45 died.

The sociodemographic profile of the studied sample had a high frequencyl ofthe age group from 20 to 34 years (58.7\%), the mean age was 25 years, the minimum 13 and the maximum $45 ; 56.8 \%$ of the women were married; $53.0 \%$ came from the capital; only $24.7 \%$ had more than nine years of schooling; $60.2 \%$ considered themselves non-white and $62.1 \%$ of women did not work. Regarding previous gestational history, the majority of women presented two or more pregnancies (53.4\%), one delivery (49.4\%) and no abortion $(77.4 \%)$.

The most prevalent life threatening conditions were the use of blood products (37.0\%), followed by severe preeclampsia (30.0\%) and eclampsia ( $23.0 \%$ ).

Table 1 shows association, in the bivariate analysis, only between the variables origin $(p=0.016)$ and potentially life threatening conditions. In the other variables, there was no such association. The relationship shows that $83.9 \%$ of the women who came from the Metropolitan Region of Fortaleza had some comorbidity.

When performing logistic regression, the age group of 20 to 34 years had a strong association $(\mathrm{p}=$ 0.007 ) and 2.5 (CI 95.0\%, 1.2-4.9, CI 95.0\% 1.0-6.0) times more likely to evolve into potentially life threatening conditions. Regarding the provenance, women from the countryside of the state $(p=0.046)$ had a significant association with life threatening conditions; these women present a $70.0 \%$ higher chance of progression to complications. 
Table 1 - Bivariate analysis and logistic regression of sociodemographic data according to potentially life threatening conditions

\begin{tabular}{|c|c|c|c|c|c|c|}
\hline \multirow{2}{*}{ Sociodemographic data } & \multicolumn{2}{|c|}{ Life threatening conditions } & \multirow[t]{2}{*}{$\mathbf{p}$} & \multirow{2}{*}{$\begin{array}{c}\text { OR }_{\text {gross }}^{*} \\
(\mathrm{CI} 95 \%)\end{array}$} & \multirow[t]{2}{*}{$\mathbf{p}$} & \multirow{2}{*}{$\begin{array}{c}\text { OR }_{\text {adjusted }} \\
\left(\text { CI95\%**) }^{*}\right)\end{array}$} \\
\hline & Yes & No & & & & \\
\hline \multicolumn{7}{|l|}{ Age $(n=560)$} \\
\hline 13 to 19 & $128(85.8)$ & $21(14.2)$ & 0.054 & & 0.223 & \\
\hline 20 to 34 & $250(76.2)$ & $78(23.8)$ & & & 0.007 & $2.5(1.2-4.9)$ \\
\hline$\geq 35$ & $64(77.1)$ & $19(22.9)$ & & & 0.032 & $2.5(1.0-6.0)$ \\
\hline \multicolumn{7}{|l|}{ Marital status $(n=505)$} \\
\hline Single & $177(81.2)$ & $41(18.8)$ & 0.440 & $1.1(0.7-1.8)$ & & \\
\hline Married & $225(78.4)$ & $62(21.6)$ & & & 0.969 & $0.9(0.6-1.6)$ \\
\hline \multicolumn{7}{|l|}{ Origin $(n=560)$} \\
\hline Fortaleza & $246(80.9)$ & $58(19.1)$ & 0.016 & & 0.053 & \\
\hline Metropolitan region & $95(83.9)$ & $18(16.1)$ & & & 0.443 & \\
\hline Countryside & $101(70.6)$ & $42(29.4)$ & & & 0.046 & $1.7(1.0-2.9)$ \\
\hline \multicolumn{7}{|l|}{ Schooling ( $n=470$ ) (years) } \\
\hline$<9$ & $286(80.8)$ & $68(19.2)$ & 0.253 & $1.3(0.8-2.2)$ & 0.580 & $1.1(0.6-2.0)$ \\
\hline$\geq 9$ & $88(75.9)$ & $28(24.1)$ & & & & \\
\hline \multicolumn{7}{|l|}{ Occupation $(n=543)$} \\
\hline Does not work & $273(81.0)$ & $64(19.0)$ & 0.111 & $1.4(0.9-2.1)$ & 0.577 & $1.1(0.6-1.9)$ \\
\hline Works & $155(75.2)$ & $51(24.8)$ & & & & \\
\hline
\end{tabular}

Table 2 - Association of cases of potentially life threatening conditions with obstetrical/clinical data

\begin{tabular}{|c|c|c|c|}
\hline \multirow[t]{2}{*}{ Variables } & \multicolumn{2}{|c|}{$\begin{array}{l}\text { Potentially life } \\
\text { threatening conditions }\end{array}$} & \multirow[t]{2}{*}{$\mathbf{p}$} \\
\hline & Yes $(n=441)$ & No $(n=119)$ & \\
\hline \multicolumn{4}{|c|}{ Type of delivery $(\mathrm{n}=523)$} \\
\hline Vaginal & $55(83.3)$ & $11(16.7)$ & 0.534 \\
\hline Cesarean section & $366(80.1)$ & $91(19.9)$ & \\
\hline \multicolumn{4}{|l|}{ Gestations $(n=526)$} \\
\hline None & $197(80.4)$ & $48(19.6)$ & 0.374 \\
\hline$\geq 1$ & $217(77.2)$ & $64(22.8)$ & \\
\hline \multicolumn{4}{|l|}{ Deliveries $(n=526)$} \\
\hline None & $7(53.8)$ & $6(46.2)$ & 0.040 \\
\hline 1 & $212(81.5)$ & $48(18.5)$ & \\
\hline$\geq 2$ & $195(77.1)$ & $58(22.9)$ & \\
\hline \multicolumn{4}{|l|}{ Abortions $(n=526)$} \\
\hline None & $316(77.6)$ & $91(22.4)$ & 0.062 \\
\hline 1 & $71(78.0)$ & $20(22.0)$ & \\
\hline$\geq 2$ & $27(96.4)$ & $1(3.2)$ & \\
\hline \multicolumn{4}{|c|}{ Previous cesarean section $(n=424)$} \\
\hline Yes & $73(76.8)$ & $22(23.2)$ & 0.556 \\
\hline No & $262(79.6)$ & $67(20.4)$ & \\
\hline \multicolumn{4}{|c|}{ Prenatal care $(\mathrm{n}=410)$ (consultations) } \\
\hline$<6$ & $195(78.9)$ & $52(21.1)$ & 0.493 \\
\hline$\geq 6$ & $124(76.1)$ & 39 (23.9) & \\
\hline
\end{tabular}

The data presented in Table 2 indicate that there was an association only in relation to the birth variable $(\mathrm{p}=0.040)$, indicating that the majority ( $81.5 \%)$ of women who had experienced only one previous birth had a potentially life threatening condition.

Although there was no statistical significance, it was observed that the highest frequency of women with potentially life-threatening conditions had vaginal delivery (83.3\%), were primigravidae (80.4\%) and had experienced two or more previous abortions (96.4\%).

Table 3 - Association between the life threatening conditions of the infant and potentially threatening conditions of maternal life

\begin{tabular}{lcccc}
\hline $\begin{array}{l}\text { Potentially life } \\
\text { threatening condi- } \\
\text { tions (n=361) }\end{array}$ & $\begin{array}{c}\mathbf{5 - m i n} \\
\text { Apgar }<7\end{array}$ & $\begin{array}{c}\text { Weight } \\
\mathbf{< 1 5 0 0 g}\end{array}$ & $\begin{array}{c}\text { Gestational age } \\
\text { at birth <30w }\end{array}$ & $\begin{array}{c}\text { Newborn } \\
\text { outcome }\end{array}$ \\
\hline Yes & $110(36.1)$ & $70(24.7)$ & $61(19.1)$ & $70(23.9)$ \\
No & $17(21.0)$ & $8(10.3)$ & $12(14.1)$ & $9(11.8)$ \\
Odds ratio (CI95\%)* & $2.1(1.1-3.8)$ & $2.8(1.3-6.2)$ & $1.4(0.7-2.8)$ & $2.3(1.1-4.9)$ \\
$X^{2 * *}$ & $\mathrm{p}=0.010$ & $\mathrm{p}=0.006$ & $\mathrm{p}=0.287$ & $\mathrm{p}=0.023$ \\
\hline${ }^{*} \mathrm{CI}=$ Confidence Interval; ${ }^{* *}$ Chi-square test & &
\end{tabular}


There was an association between two of the three variables related to the infant and the potentially life threatening conditions of mothers. The statistical association shows that mothers who had experienced some serious morbidity were 2.1 (CI 95.0\%1.1-13.8) times more likely to have a child with 5-minute Apgar $<7$ and 2.8 (CI 95.0\% 1,3-6,2) more likely to have children weighing less than $1,500 \mathrm{~g}$. In the present study, potentially life threatening conditions indicate 2.3 (CI 95.0\% 1.1-4.9) times higher chance of perinatal death.

\section{Discussion}

As a limitation of the study, we can be point out the fact that the data were collected from medical records, which did not allow to characterize some criteria because some missing data in the medical records, as well as the failure to perform exams in cases of obstetric complications, which also made it difficult to identify these cases of morbidity. As notes for future studies, further research must be designed in the form of case-control study to show the differences between women with and without unfavorable maternal outcomes, and cohort studies on the precision of the effects and sequelae from morbidities during the life of these women.

Another limitation for accurately identifying maternal morbidity was admission to the intensive care unit as an objective inclusion criterion. It is known that admission to the intensive care unit depends on several factors, such as accessibility and availability of vacancies in the unit. For this reason, it is possible that not all women with potentially life threatening conditions actually received intensive care.

Regarding the main potentially life threatening conditions found, the findings corroborate a study carried out in 2011, in which the main causes were blood transfusion (57.6\%) and preeclampsia $(41.5 \%)^{(10)}$. In this study 754 bags of packed red blood cells were transfused, representing an average of 3.6 bags per patient. This is not surprising since transfusion therapy is expected in women admitted to Intensive Care Units, especially in those who have hemorrhagic syndrome, because this is part of the treatment for this condition.

The high percentage of women residing in the capital and metropolitan region is explained by the proximity to the hospital, and also because this is a reference Maternity. However, the high percentage of women residing in municipalities of the countryside of the state with severe morbidity is also noteworthy. This probably reflects the precariousness of care provided in these localities and the need for improvements that can be achieved through organization of regional assistance and decentralization of prenatal and high-risk childbirth care, providing these regions with specialized equipment, medicines and professionals.

Regarding age, one study concluded that the rates of maternal complications increase with age ${ }^{(11)}$. However, recent research has identified a higher occurrence of Near miss morbidity and mortality in women aged 20 to 29 years $^{(12-13)}$.

Although the variables marital status, schooling and occupation were not statistically significant, it is important to note that, on marital status, the presence of partners is important in the life of the pregnant/puerperal women, since the partner can provide emotional and economic support to them. Regarding schooling and occupation, we believe that women with more years of schooling and paid employment have better socioeconomic conditions and, therefore, can take better care of their health and experience less complications.

Regarding maternal complications related to parity, the data found corroborate with the more recent literature that shows primiparity as a risk factor for these complications ${ }^{(12)}$.

Regarding the variable abortion, this is considered a risk factor for cases of potentially life threatening conditions and is linked to other indicators for maternal death, such as maternal age, low schooling, 
multiparity and inadequate prenatal, and normally occurs due to complications during labor ${ }^{(14)}$. A systematic review of the literature in 11 countries, which associated abortion and maternal Near miss, identified that $6.3 \%$ of cases of abortion progressed to Near miss and $0.3 \% \operatorname{died}^{(15)}$.

Among the obstetric antecedents, the issue of the previous cesarean section also stands out. The excess of cesarean sections in Brazil is still a great challenge to be faced by the maternal health area; approximately 1.6 million cesarean sections are performed every year. In the last decades, the national rate of cesarean sections has increased progressively and is currently around $56.0 \%$. When considering the supplementary health situation, this is even worse, since it presents a rate of $85.0 \%{ }^{(16)}$.

There was no association between the number of prenatal consultations and the incidence of complications. However, the studies state that the absence of prenatal care or inadequate follow-up exacerbates a potentially life threatening condition, delaying possible diagnosis and early treatment ${ }^{(17)}$.

The results show that the maternal conditions of pregnancy and childbirth influence fetal and neonatal conditions. The presence of any comorbidity may contribute to the increase of perinatal morbidity and mortality ${ }^{(7)}$.

In a recent study, the proportion of underweight children was higher among mothers with complications $(44.4 \%, \mathrm{p}<0.001)$. The logistic regression analysis of the study also revealed a significant association between stillbirth maternal complications (OR = 5.40; CI 95.0\% [2.18-13.40]), low birth weight (OR $=3.38$; CI 95.0\% [1.61-7.06]) and post-term newborn $(\mathrm{OR}=3.24 ; \mathrm{CI} 95.0 \% \text { [1.51-6.97] })^{(18)}$.

Besides the increased risk of fetal death, newborns of women with complications are at higher risk of dying in the first week of life, or require intensive health care, or to be smaller than the normal for the gestational age ${ }^{(7)}$.

In this sense, the results can contribute to the surveillance of maternal morbimortality and for a better and wider knowledge for clinical practice. This may lead to improvements in the quality of care to women in the pregnancy-puerperal period, as well as the need to study the course of these women during care to identify possible obstetric delays. These needs may be minimized when more attention is paid to the stratification of risk that pregnant women experience during the prenatal follow-up.

\section{Conclusion}

The most prevalent life threatening conditions were the use of blood products, followed by severe preeclampsia and eclampsia. A strong relation between origin, parity and potentially life threatening conditions was identified, as well as the association between these and negative perinatal outcomes.

\section{Collaborations}

Montes AS and Damasceno AKC contributed to the design of the project, collection, analyses and interpretation of the data. Teles LMR, Costa CC and Gomes LFS contributed to the writing of the article, relevant critical revision of the intellectual content and final approval of the version to be published.

\section{References}

1. Áfio ACE, Araújo MAL, Rocha AFB, Andrade RFV, Melo SP. Maternal deaths: the need to rethink coping strategies. Rev Rene. 2014; 15(4):6318. doi: http://dx.doi.org/10.15253/21756783.2014000400010.

2. Ministério da Saúde (BR). Secretaria de Vigilância em Saúde. Boletim epidemiológico: mortalidade materna. Brasília: Ministério da Saúde; 2013.

3. Secretaria de Saúde do Estado do Ceará (CE). Núcleo de Vigilância Epidemiológica. Boletim Epidemiológico: Mortalidade Materna, Infantil e Fetal. Fortaleza: Secretaria de Saúde do Estado do Ceará; 2016. 
4. Chhabra P. Maternal Near miss: an indicator for maternal health and maternal care. Indian J Community Med. 2014; 39(3):132-7. doi: http:// dx.doi.org/10.4103/0970-0218.137145

5. Rocha Filho EA, Costa ML, Cecatti JG, Parpinelli MA, Haddad SM, Sousa MH, et al. Contribution of antepartum and intrapartum hemorrhage to the burden of maternal Near miss and death in a national surveillance study. Acta Obstet Gynecol Scand. 2015; 94(1):50-8. doi: http://dx.doi. org/10.1111/aogs.12529

6. Shen FR, Liu M, Zhang X, Yang W, Chen YG. Factors associated with maternal near-miss morbidity and mortality in Kowloon Hospital, Suzhou, China. Int J Gynecol Obstet. 2013; 123(1):64-7. doi: http://dx.doi.org/10.1016/j.ijgo.2013.06.01

7. Menezzi AMED, Figueiredo ID, Lima EWB, Almeida JC, Marques FKS, Oliveira CF. Vigilância do óbito fetal: estudo das principais causas. Mundo Saúde. 2016; 40(2):208-12

8. Silva AAM, Leite AJM, Lamy ZC,Moreira MEL,Gurgel RQ Cunha AJL, et al. Neonatal near miss in the Birth in Brazil survey. Cad Saúde Pública. 2014;30 (Suppl 1):182-91. doi: http:// dx.doi.org/10.1590/0102-311X00129613

9. World Health Organization. Evaluating the quality of care for severe pregnancy complications: The WHO near-miss approach for maternal health. Geneva: World Health Organization; 2014.

10. Tunçalp O, Hindin MJ, Bonsaffoh KA, Adanu R. Assessment of maternal near-miss and quality of care in a hospital-based study in Accra, Ghana. Int J Gynecol Obstet. 2013; 123(1):58-63. doi: http:// dx.doi.org/10.1016/j.ijgo.2013.06.003

11. Oliveira LC, Costa AAR. Fetal and neonatal deaths among cases of maternal near miss. Rev Assoc Med Bras. 2013; 59(5):487-94. doi: http://dx.doi.org/10.1016/j.ramb.2013.08.004
12. Giordano JC, Parpinelli MA, Cecatti JG, Haddad SM, Costa ML, Surita FG, et al. The burden of eclampsia: results from a multicenter study on surveillance of severe maternal morbidity in Brazil. PLoS One. 2014; 9(5):97-101. doi: http:// dx.doi.org/10.1371/journal.pone.0097401

13. Assarag B, Dujardin B, Delamou A, Meski F, Brouwere V. Determinants of maternal nearmiss in morocco: too late, too far, too sloppy?. PLoS One. 2015; 10(1):22-30. doi: http://dx.doi. org/10.1371/journal.pone.0116675

14. Destêrro R, Lima SM, França LG, Lima RDSM. Perfil clínico-epidemiológico de mulheres em situação de Abortamento em uma maternidade pública de São Luís- MA. Rev Investig Bioméd. 2015; 1(7):1223.

15. Adler JA, Filippi V, Thomas SL, Ronsmans C. Incidence of severe acute maternal morbidity associated with abortion: a systematic review. Trop Med Int Health. 2012; 17(2):177-90. doi: http:// dx.doi.org/10.1111/j.1365-3156.2011.02896.x

16. Ministério da Saúde (BR). Secretaria de Ciência, Tecnologia e Insumos Estratégicos. Diretrizes de atenção à gestante: a operação cesariana. Brasília: Ministério da Saúde; 2016.

17. Galvão LPL, Alvim-Pereira F, Mendonça CMM, Menezes FEF, Góis KAM, Ribeiro Jr RF, et al. The prevalence of severe maternal morbidity and Near miss and associated factors in sergipe, northeast brazil. bmc pregnancy and childbirth. 2014; 14(25):1-8. doi: http://dx.doi.org/10.1186/1471-2393-1425

18. Adeoye IA, Onayade AA, Fatusi AO. Incidence, determinants and perinatal outcomes of Near miss maternal morbidity in Ile-Ife Nigeria: a prospective case control study. BMC Pregnancy Childbirth. 2013; 13(93):1-10. doi: http://dx.doi. org/10.1186/1471-2393-13-93 